\title{
Environmental factors controlling spatial variation in sediment yield in a central Andean mountain area
}

\author{
Armando Molina ${ }^{\mathrm{a}, *}$, Gerard Govers ${ }^{\mathrm{a}}$, Jean Poesen ${ }^{\mathrm{a}}$, Hendrik Van Hemelryck ${ }^{\mathrm{a}}$, \\ Bert De Bièvre $^{\mathrm{a}, \mathrm{c}}$, Veerle Vanacker ${ }^{\mathrm{b}}$ \\ ${ }^{a}$ Physical and Regional Geography Research Group, Katholieke Universiteit Leuven, Celestijnenlaan 200E, 3001 Heverlee, Belgium \\ b Département de Géographie, Université Catholique de Louvain, 3 Place Louis Pasteur, 1348 Louvain-la-Neuve, Belgium \\ ${ }^{\mathrm{c}}$ Programa para el Manejo del Agua y del Suelo (PROMAS), Universidad de Cuenca, Av. 12 de abril s/n, Cuenca, Ecuador
}

Received 5 January 2006; received in revised form 12 May 2006; accepted 20 December 2006

\begin{abstract}
A large spatial variability in sediment yield was observed from small streams in the Ecuadorian Andes. The objective of this study was to analyze the environmental factors controlling these variations in sediment yield in the Paute basin, Ecuador. Sediment yield data were calculated based on sediment volumes accumulated behind checkdams for 37 small catchments. Mean annual specific sediment yield (SSY) shows a large spatial variability and ranges between 26 and 15,100 $\mathrm{Mg} \mathrm{km}^{-2}$ year $^{-1}$. Mean vegetation cover $(\mathrm{C}$, fraction) in the catchment, i.e. the plant cover at or near the surface, exerts a first order control on sediment yield. The fractional vegetation cover alone explains $57 \%$ of the observed variance in $\ln (\mathrm{SSY})$. The negative exponential relation ( SSY $=a \times e^{-b C}$ ) which was found between vegetation cover and sediment yield at the catchment scale $\left(10^{3}-10^{9} \mathrm{~m}^{2}\right)$, is very similar to the equations derived from splash, interrill and rill erosion experiments at the plot scale $\left(1-10^{3} \mathrm{~m}^{2}\right)$. This affirms the general character of an exponential decrease of sediment yield with increasing vegetation cover at a wide range of spatial scales, provided the distribution of cover can be considered to be essentially random. Lithology also significantly affects the sediment yield, and explains an additional $23 \%$ of the observed variance in $\ln (\mathrm{SSY})$. Based on these two catchment parameters, a multiple regression model was built. This empirical regression model already explains more than $75 \%$ of the total variance in the mean annual sediment yield. These results highlight the large potential of revegetation programs for controlling sediment yield. They show that a slight increase in the overall fractional vegetation cover of degraded land is likely to have a large effect on sediment production and delivery. Moreover, they point to the importance of detailed surface vegetation data for predicting and modeling sediment production rates.
\end{abstract}

(C) 2007 Elsevier B.V. All rights reserved.

Keywords: Erosion; Vegetation; Land use; Sediment yield; Checkdams; Andes

\section{Introduction}

Tropical mountain areas are highly susceptible to soil erosion due to their rough topography and erosive

\footnotetext{
* Corresponding author. Tel.: +32 16 326405; fax: +32 16326400 .

E-mail address: Armando.MolinaVerdugo@geo.kuleuven.be
} (A. Molina) climate (Dadson et al., 2003). In Andean regions, the human population was traditionally concentrated in the intermontane valleys because of their favourable climate, topography and fertile soils. Increasing land pressure due to demographic growth and socio-economic development has induced a spatial redistribution of the population. In search of new livelihoods, more people were forced to migrate towards steep hillsides 
and highlands. These areas are less favourable for agriculture, and are particularly sensitive to soil erosion by water (Vanacker et al., 2003a), tillage (Dercon et al., 2007) and landsliding (Hess, 1990; Wunder, 1996; Vanacker et al., 2003b).

Nowadays, severe land degradation is reported in many tropical mountain areas worldwide. Studies (Hewawasam et al., 2003; Vanacker et al., 2007) have shown that human activities have accelerated mountain erosion rates by up to 100 times. Accelerated soil erosion may jeopardize future socio-economic development. First, the loss of soil nutrients augments the costs of food production by reducing the natural crop productivity (Pimentel et al., 1995). Second, the transport of excessive sediment loads in the river system causes severe damage to infrastructure and also limits the use of surface water for drinking water production and hydropower generation (Palmieri et al., 2001).

Understanding the environmental factors controlling soil erosion is crucial to assess the potential impact of soil erosion mitigation strategies. This problem has tradition- ally been studied by analyzing soil erosion processes at the scale of hillslope erosion plots $\left(10^{-6}-10^{-2} \mathrm{~km}^{2}\right)$ (e.g. Cerda, 1998), or by looking at sediment yield at the scale of large catchments $\left(10^{2}-10^{4} \mathrm{~km}^{2}\right)$ (e.g. de Vente et al., 2004). While erosion plots provide relevant information, they do not include all processes contributing to sediment delivery (de Vente and Poesen, 2005). In mountain areas, the sediment budget is not only controlled by water erosion processes on arable land, but also by gully erosion over overgrazed steeplands as well as by infrequent influxes of sediment from landslides, debris flows and bank erosion (Froehlich and Starkel, 1995; Montgomery and Buffington, 1997). These processes integrate over larger spatial scales, and are typically not included in traditional comparative plot studies (Trimble and Crosson, 2000). The latter approach, i.e. analyzing the environmental controls on sediment yield at the scale of large catchments $\left(10^{2}-10^{4} \mathrm{~km}^{2}\right)$, is often hampered by the limited number of gauging stations and the large heterogeneity of climate, vegetation, land use and topography within the large catchments.

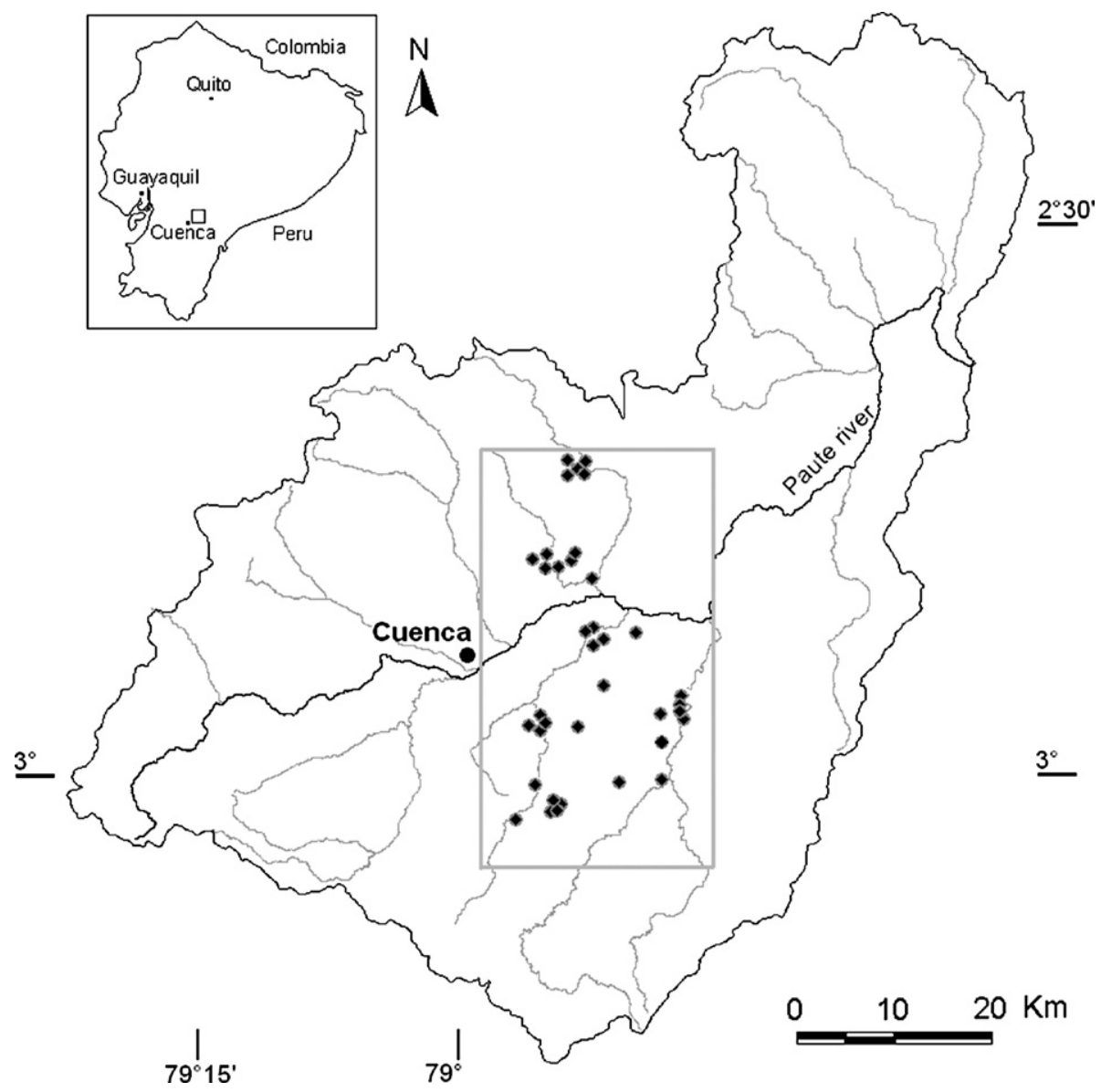

Fig. 1. Location of the outlet of the 37 studied catchments (given by black diamonds) in the southern Ecuadorian Andes. 
Small catchments $\left(10^{-2}-10^{2} \mathrm{~km}^{2}\right)$ integrate all relevant processes, as the spatial heterogeneity of controlling factors within the catchments is relatively limited. Therefore, small catchments present the ideal scale for identifying factors controlling overall sediment yield. However, sediment yield data at this scale are often lacking due to the absence of permanent gauging stations and/or reservoirs (de Vente and Poesen, 2005). In this study, we present spatially distributed erosion data from 37 small catchments $\left(10^{-2}-10^{2} \mathrm{~km}^{2}\right)$ in the Ecuadorian Andes which were obtained by measuring the sediment volumes stored behind checkdams. First, we discuss the spatial variability in sediment yield within a larger intermontane basin. Second, we analyze the environmental variables that control erosion at the scale of small catchments $\left(10^{-2}-10^{2} \mathrm{~km}^{2}\right)$.

\section{Materials and methods}

\subsection{Study area}

Soil erosion and sediment production were studied in the central part of the Cuenca intermontane basin, located between 2300 and $3300 \mathrm{~m}$ a.s.l. (Fig. 1). The region has a typical tropical mountain climate. Average monthly air temperatures show little variation (between $15^{\circ} \mathrm{C}$ in January and $14{ }^{\circ} \mathrm{C}$ in August in Cuenca, at $2530 \mathrm{~m}$ a.s.l.). Rainfall regime is bimodal with two rainy seasons, registering between 600 and $1000 \mathrm{~mm}$ of yearly rainfall.

Morphologically, this area can be subdivided in two parallel ridges, the Eastern and Western Cordillera, which are separated by a tectonic depression approximately $25 \mathrm{~km}$ wide. The Eastern Cordillera is essentially composed of Palaeozoic to Cretaceous metamorphic rocks and has local intrusions of diorite and granodiorite. The Western Cordillera is represented by a series of Late Mesozoic and Tertiary sedimentary deposits and interstratified volcanic material. Prior to tectonic uplift, Upper Miocene to Upper Pliocene volcanoclastic deposits covered both Cordilleras. The InterAndean tectonic depression was created during the PlioPleistocene, and comprises a thick sequence of continental detrital deposits and interstratified volcanic material (Coltorti and Ollier, 2000). Active tectonics created steep topography: more than $60 \%$ of the area has slope gradients steeper than $0.3 \mathrm{~m} \mathrm{~m}^{-1}$.

The main factors controlling soil formation in the central part of this intermontane basin are local topography, climate regime and parent material. In the upper parts of the basin, soils are generally well drained and characterized by a high water content and high infiltration rates (Dercon et al., 1998). According to the WRB (World
Reference Base) classification, dominant soil types are Andosols, Umbrisols and Luvisols (Deckers et al., 1998). In the middle and lower parts of the basin, soil types vary from Leptosols and Regosols on steep slopes, to Luvisols, Cambisols and Vertisols on areas of moderate slope gradient. Leptosols and Regosols are limited in depth by continuous hard rock or weathered material. In contrast, Luvisols, Cambisols and Vertisols are deep and mostly composed of clayey material.

Human activities have greatly modified the natural environment. The lower and middle parts of the Cuenca intermontane basin, which have favourable climatic and topographic conditions, are densely populated. Land cover is dominated by urban and agricultural land. However, low agricultural productivity due to intense soil erosion has led to land abandonment and reforestation of badlands with eucalyptus and pine trees (Vanacker et al., 2003a). The sub-páramo land located in the upper parts of the catchment were largely covered by forest until the $1960 \mathrm{~s}$, but agrarian land reforms and demographic growth brought massive conversion of these forests into rangeland (Commander and Peek, 1986). This process has been accelerated by road building.

Increasing awareness about sediment production in the area led to the construction of checkdams in several zero-order catchments in the 1990s. By establishing sediment infilling rates behind the checkdams, an estimate can be obtained of the mean annual sediment yield of the catchment over several years. In total, 37 catchments were identified as suitable for these measurements. Although the presence of checkdams was the main factor controlling catchment selection for this research, the 37 selected catchments also represent the variability in lithology, topography, land cover, and soils within the degraded areas of the lower and middle part of the Cuenca intermontane basin (Fig. 1, Table 1).

\subsection{Sediment yield data}

Sediment deposition was assessed by direct measurements of the accumulated sediment volumes behind 106 checkdams located within 37 catchments. These dams were constructed in ephemeral streams in the 1990s for sediment trapping and stream stabilization (Fig. 2). By reducing the steepness of the stream channels, they restrain the erosive power of storm events (Aristide, 2002). The volume of sediment deposited behind the checkdams ranges between 13 and $5477 \mathrm{~m}^{3}$, and their drainage area varies between 0.02 and $16.12 \mathrm{~km}^{2}$ (Table 1). 
Table 1

Data collected for the 37 surveyed catchments in the southern Ecuadorian Andes

\begin{tabular}{|c|c|c|c|c|c|c|c|c|c|}
\hline \multirow[b]{2}{*}{ Catchment } & \multirow[b]{2}{*}{ Longitude } & \multirow[b]{2}{*}{ Latitude } & \multirow{2}{*}{$\begin{array}{l}\text { Sediment yield }{ }^{\mathrm{a}} \\
\left(\mathrm{Mg} \mathrm{km}^{-2} \text { year }^{-1}\right) \\
\mathrm{SSY}\end{array}$} & \multirow{2}{*}{$\begin{array}{l}\text { Catchment } \\
\text { area }\left(\mathrm{km}^{2}\right) \\
A\end{array}$} & \multirow{2}{*}{$\begin{array}{l}\text { Vegetation } \\
\text { cover }(/) \\
C\end{array}$} & \multirow{2}{*}{$\frac{\begin{array}{l}\text { Mean slope } \\
\left(\mathrm{m} \mathrm{m}^{-1}\right)\end{array}}{\mathrm{SL}}$} & \multirow{2}{*}{$\begin{array}{l}\text { Relief } \\
\text { ratio (/) } \\
\mathrm{RR}\end{array}$} & \multirow{2}{*}{$\begin{array}{l}\begin{array}{l}\text { Highly erodible } \\
\text { soils }{ }^{\mathrm{b}}(/)\end{array} \\
\text { SOIL }\end{array}$} & \multirow{2}{*}{$\begin{array}{l}\text { Argillaceous } \\
\operatorname{rocks}^{\mathrm{c}}(/) \\
L\end{array}$} \\
\hline & & & & & & & & & \\
\hline Valdivieso1 & $78^{\circ} 52^{\prime} 46.4^{\prime \prime}$ & $2^{\circ} 52^{\prime} 13.3^{\prime \prime}$ & 2200 & 0.03 & 0.53 & 0.54 & 0.55 & 0.85 & 0.90 \\
\hline Valdivieso3 & $78^{\circ} 52^{\prime} 44.3^{\prime \prime}$ & $2^{\circ} 52^{\prime} 11.6^{\prime \prime}$ & 2180 & 0.04 & 0.52 & 0.58 & 0.53 & 0.88 & 0.85 \\
\hline Belga & $78^{\circ} 52^{\prime} 31.4^{\prime \prime}$ & $2^{\circ} 52^{\prime} 07.4^{\prime \prime}$ & 140 & 9.42 & 0.82 & 0.27 & 0.07 & 0.08 & 0.47 \\
\hline Vegaspamba & $78^{\circ} 52^{\prime} 33.1^{\prime \prime}$ & $2^{\circ} 52^{\prime} 13.1^{\prime \prime}$ & 5800 & 0.25 & 0.18 & 0.41 & 0.29 & 0.07 & 0.96 \\
\hline Siptag & $78^{\circ} 48^{\prime} 42.3^{\prime \prime}$ & $3^{\circ} 00^{\prime} 10.7^{\prime \prime}$ & 3200 & 0.08 & 0.37 & 0.41 & 0.36 & 0.00 & 0.90 \\
\hline Macas & $78^{\circ} 56^{\prime} 53.8^{\prime \prime}$ & $3^{\circ} 02^{\prime} 25.3^{\prime \prime}$ & 7580 & 0.04 & 0.13 & 0.33 & 0.27 & 0.07 & 0.96 \\
\hline Monjas & $78^{\circ} 53^{\prime} 32.2^{\prime \prime}$ & $2^{\circ} 57^{\prime} 18.4^{\prime \prime}$ & 150 & 1.12 & 0.98 & 0.20 & 0.18 & 0.00 & 0.76 \\
\hline Caldera & $78^{\circ} 54^{\prime} 33.0^{\prime \prime}$ & $2^{\circ} 48^{\prime} 18.5^{\prime \prime}$ & 15,100 & 1.48 & 0.16 & 0.39 & 0.18 & 0.61 & 0.94 \\
\hline Mesaloma2 & $78^{\circ} 53^{\prime} 52.3^{\prime \prime}$ & $2^{\circ} 47^{\prime} 58.7^{\prime \prime}$ & 1820 & 0.02 & 0.49 & 0.40 & 0.34 & 0.50 & 0.80 \\
\hline Mesaloma1 & $78^{\circ} 53^{\prime} 52.3^{\prime \prime}$ & $2^{\circ} 47^{\prime} 59.0^{\prime \prime}$ & 1490 & 0.02 & 0.35 & 0.36 & 0.35 & 0.50 & 0.78 \\
\hline Autopista & $78^{\circ} 52^{\prime} 43.8^{\prime \prime}$ & $2^{\circ} 48^{\prime} 59.0^{\prime \prime}$ & 13,700 & 0.04 & 0.17 & 0.26 & 0.19 & 0.00 & 0.97 \\
\hline Llayshatan & $78^{\circ} 50^{\prime} 19.5^{\prime \prime}$ & $2^{\circ} 52^{\prime} 11.7^{\prime \prime}$ & 26 & 0.07 & 0.90 & 0.28 & 0.25 & 0.95 & 0.17 \\
\hline Peste & $78^{\circ} 47^{\prime} 39.9^{\prime \prime}$ & $2^{\circ} 55^{\prime} 31.7^{\prime \prime}$ & 140 & 7.12 & 0.68 & 0.40 & 0.23 & 0.00 & 0.23 \\
\hline Uzhar1 & $78^{\circ} 47^{\prime} 44.9^{\prime \prime}$ & $2^{\circ} 55^{\prime} 59.7^{\prime \prime}$ & 610 & 0.59 & 0.32 & 0.50 & 0.30 & 0.00 & 0.11 \\
\hline Uzhar2-3 & $78^{\circ} 47^{\prime} 43.7^{\prime \prime}$ & $2^{\circ} 56^{\prime} 10.9^{\prime \prime}$ & 430 & 2.40 & 0.46 & 0.42 & 0.26 & 0.00 & 0.75 \\
\hline Agupancay & $78^{\circ} 47^{\prime} 37.0^{\prime \prime}$ & $2^{\circ} 56^{\prime} 38.3^{\prime \prime}$ & 160 & 16.12 & 0.67 & 0.39 & 0.13 & 0.00 & 0.85 \\
\hline San Juan & $78^{\circ} 48^{\prime} 33.1^{\prime \prime}$ & $2^{\circ} 59^{\prime} 18.0^{\prime \prime}$ & 84 & 2.31 & 0.68 & 0.55 & 0.32 & 0.00 & 0.15 \\
\hline Arug & $78^{\circ} 51^{\prime} 10.5^{\prime \prime}$ & $3^{\circ} 00^{\prime} 12.1^{\prime \prime}$ & 110 & 1.51 & 0.79 & 0.50 & 0.28 & 0.00 & 0.70 \\
\hline Dungla & $78^{\circ} 48^{\prime} 55.0^{\prime \prime}$ & $2^{\circ} 56^{\prime} 45.2^{\prime \prime}$ & 1360 & 0.16 & 0.69 & 0.34 & 0.27 & 0.00 & 1.00 \\
\hline Llanapay & $78^{\circ} 55^{\prime} 43.4^{\prime \prime}$ & $3^{\circ} 00^{\prime} 25.9^{\prime \prime}$ & 70 & 4.56 & 0.70 & 0.44 & 0.18 & 0.72 & 0.58 \\
\hline Quingeo1 & $78^{\circ} 54^{\prime} 54.7^{\prime \prime}$ & $3^{\circ} 01^{\prime} 46.3^{\prime \prime}$ & 340 & 7.35 & 0.96 & 0.29 & 0.09 & 0.00 & 0.92 \\
\hline Quingeo2 & $78^{\circ} 54^{\prime} 51.5^{\prime \prime}$ & $3^{\circ} 01^{\prime} 46.7^{\prime \prime}$ & 650 & 4.28 & 0.83 & 0.28 & 0.12 & 0.00 & 0.87 \\
\hline Quingeo3 & $78^{\circ} 54^{\prime} 32.1^{\prime \prime}$ & $3^{\circ} 01^{\prime} 21.9^{\prime \prime}$ & 290 & 1.30 & 0.63 & 0.36 & 0.19 & 0.00 & 0.82 \\
\hline Quingeo4 & $78^{\circ} 54^{\prime} 52.5^{\prime \prime}$ & $3^{\circ} 01^{\prime} 14.8^{\prime \prime}$ & 210 & 11.45 & 0.84 & 0.37 & 0.12 & 0.00 & 0.55 \\
\hline Carmen1 & $78^{\circ} 52^{\prime} 10.8^{\prime \prime}$ & $2^{\circ} 55^{\prime} 00.3^{\prime \prime}$ & 670 & 3.37 & 0.90 & 0.24 & 0.15 & 0.00 & 0.85 \\
\hline Cachi & $78^{\circ} 55^{\prime} 44.8^{\prime \prime}$ & $2^{\circ} 56^{\prime} 54.2^{\prime \prime}$ & 4650 & 0.77 & 0.35 & 0.38 & 0.20 & 0.35 & 0.94 \\
\hline Salado & $78^{\circ} 55^{\prime} 39.9^{\prime \prime}$ & $2^{\circ} 57^{\prime} 20.9^{\prime \prime}$ & 650 & 0.56 & 0.37 & 0.36 & 0.21 & 0.06 & 0.73 \\
\hline Antonio & $78^{\circ} 55^{\prime} 38.3^{\prime \prime}$ & $2^{\circ} 56^{\prime} 29.2^{\prime \prime}$ & 3860 & 0.26 & 0.37 & 0.36 & 0.22 & 0.49 & 1.00 \\
\hline El Chorro & $78^{\circ} 55^{\prime} 46.9^{\prime \prime}$ & $2^{\circ} 57^{\prime} 02.1^{\prime \prime}$ & 2050 & 0.17 & 0.64 & 0.44 & 0.34 & 0.48 & 0.95 \\
\hline Aguasanta & $78^{\circ} 53^{\prime} 35.0^{\prime \prime}$ & $2^{\circ} 42^{\prime} 58.5^{\prime \prime}$ & 1490 & 0.33 & 0.44 & 0.29 & 0.20 & 0.00 & 0.61 \\
\hline San juan 1 & $78^{\circ} 53^{\prime} 31.6^{\prime \prime}$ & $2^{\circ} 42^{\prime} 49.0^{\prime \prime}$ & 1020 & 2.08 & 0.64 & 0.34 & 0.18 & 0.48 & 0.45 \\
\hline Turupamba1 & $78^{\circ} 53^{\prime} 35.3^{\prime \prime}$ & $2^{\circ} 42^{\prime} 53.5^{\prime \prime}$ & 1690 & 2.90 & 0.69 & 0.32 & 0.18 & 0.22 & 1.00 \\
\hline Turupamba2 & $78^{\circ} 53^{\prime} 27.6^{\prime \prime}$ & $2^{\circ} 42^{\prime} 52.4^{\prime \prime}$ & 1780 & 3.30 & 0.66 & 0.32 & 0.17 & 0.19 & 1.00 \\
\hline Turupamba3 & $78^{\circ} 53^{\prime} 24.9^{\prime \prime}$ & $2^{\circ} 42^{\prime} 52.3^{\prime \prime}$ & 1820 & 5.47 & 0.65 & 0.32 & 0.17 & 0.28 & 0.90 \\
\hline Salado1 & $78^{\circ} 55^{\prime} 50.7^{\prime \prime}$ & $2^{\circ} 47^{\prime} 41.7^{\prime \prime}$ & 1020 & 1.31 & 0.46 & 0.23 & 0.11 & 0.06 & 0.73 \\
\hline Salado2 & $78^{\circ} 55^{\prime} 46.0^{\prime \prime}$ & $2^{\circ} 47^{\prime} 51.2^{\prime \prime}$ & 1500 & 1.94 & 0.46 & 0.24 & 0.11 & 0.06 & 0.51 \\
\hline Negra & $78^{\circ} 55^{\prime} 10.6^{\prime \prime}$ & $2^{\circ} 48^{\prime} 22.1^{\prime \prime}$ & 870 & 3.36 & 0.45 & 0.22 & 0.13 & 0.03 & 0.19 \\
\hline
\end{tabular}

a The mean annual sediment yield $\left(\mathrm{Mg} \mathrm{km}^{-2}\right.$ year $\left.^{-1}\right)$ is estimated from checkdam infillings. The total error on the SSY estimates typically ranges between $40 \%$ and $50 \%$ (Verstraeten and Poesen, 2002).

$\mathrm{b}$ The proportion of the catchment consisting of highly erodible soil was defined as the percentage of the catchment area covered with Regosol and Leptosol (Deckers et al., 1998; PROMAS, 2001).

c The proportion of the catchment underlain by argillaceous rocks (lutites and argillaceous sandstone) and pyroclastic deposits was derived from 1/50,000 geological maps (DINAGE, 1974).

The mean annual specific sediment yield, SSY $\left(\mathrm{Mg} \mathrm{km}^{-2}\right.$ year $\left.^{-1}\right)$, was calculated as

$S S Y=M /(A * Y * \mathrm{STE})$

where $A=$ catchment area $\left(\mathrm{km}^{2}\right), Y=$ filling time of the checkdams (years), STE $=$ sediment trap efficiency $(\%)$, and $M=$ accumulated sediment mass $(\mathrm{Mg})$ (Verstraeten and Poesen, 2002). The latter was derived from the accumulated sediment volume, $S\left(\mathrm{~m}^{3}\right)$, measured on 106 checkdams in 2003 and 2005, using the average dry bulk density of the deposited material, $\rho_{\mathrm{s}}\left(\mathrm{Mg} \mathrm{m}^{-3}\right)$. Most of the checkdams consist of gabions reinforced with concrete, resulting in little water loss before the checkdam is actually overtopped. Considering this as well as the relatively coarse nature of the sediments transported, the trap efficiency for these small constructions is estimated to be $90 \%$ during their filling time. 
Values for the dry sediment bulk density, $\rho_{\mathrm{s}}$, were obtained by the gravimetric method for 11 out of 37 catchments. Fifty-five undisturbed sediment samples were taken using a Kopecky core sampler. The dry sediment bulk density for these sites varies from $0.93 \mathrm{Mg} \mathrm{m}^{-3}$ to $1.82 \mathrm{Mg} \mathrm{m}^{-3}$, with an average of $1.35 \pm 0.24 \mathrm{Mg} \mathrm{m}^{-3}$. An average value of $1.35 \mathrm{Mg} \mathrm{m}^{-3}$ was used as a first estimate for the dry bulk density in the 26 unsampled catchments.

The total error (TE) on the annual sediment yield estimated using the above-mentioned method typically ranges between 40 and 50\% (Verstraeten and Poesen, 2002). This encompasses errors due to uncertainty in the estimated filling time of the checkdams, the accumulated sediment mass as well as errors related to the estimation of STE. As all checkdams within this study area have similar characteristics, the bias associated with the estimated trap efficiency can be assumed as being systematic for this study. As we used a value of $90 \%$ for the STE of all checkdams, and made conservative estimates of the filling time based on multiple interviews with local residents, the sediment yield values reported here are conservative estimates of the annual sediment yield in the Southern Ecuadorian Andes.

\subsection{Catchment characteristics}

Topography, geology, soil type and land cover may all affect the sediment yield of a small catchment. Data on catchment characteristics were obtained from various sources, and their accuracy will often depend on the scale at which the data were originally collected. It is clear that data collected at fine scale (such as topography and land cover) better reflect the local conditions than those obtained from coarse-scale maps (such as soil type and geology).

Topographic maps of INECEL (1992, scale 1/10,000) were used to delineate the catchments and to calculate their area. The morphological analysis is based on the digital elevation model (DEM) with a resolution of $10 \mathrm{~m}$. The mean slope gradient $\left(\mathrm{m} \mathrm{m}^{-1}\right)$ and relief ratio $\left(\mathrm{m} \mathrm{m}^{-1}\right)$ were calculated for each catchment (Strahler, 1964). A digital version of the $1 / 50,000$ soil map surveyed by PRONAREG (MAG, 1979) was used to derive the major soil types within the catchments. Soil types were converted into the World Reference Base classification system and were regrouped according to their susceptibility to soil erosion (Deckers et al., 1998; PROMAS, 2001). The lithology within the catchments was characterized from the $1 / 50,000$ geological map of the area (DINAGE, 1974), which was updated using the 1/500,000 geological map of the southern Cordillera Real
(Litherland et al., 1994). The proportion of each catchment underlain by argillaceous rocks (argillaceous sandstone and so-called lutites by Litherland et al., 1994, including shales, siltstone, mudstone and claystone), and young pyroclastic deposits was estimated from the lithological maps; and later verified in the field (Table 1).

Land cover, and in particular vegetation cover, is one of the key factors regulating the surface hydrology in humid climate regimes. Vegetation cover protects the surface from raindrop impact, controls the infiltration rate, and reduces surface runoff(Thornes, 2001). Hence, dense surface vegetation cover decreases soil erosion risks (Snelder and Bryan, 1995). Land cover maps were combined with data from small vegetation plots to calculate the fractional surface cover, i.e., the vegetation cover at or very close $(<0.1 \mathrm{~m})$ to the surface, of each catchment (Fig. 3). Land cover maps were derived from aerial photographs of 1995, which have an approximate scale of $1 / 35,000$, and were updated during an extensive field campaign in 2005. Seven distinct land cover classes were identified (native forest, eucalyptus forest, pine forest, rangeland, arable land, shrubland, and barren land) and delineated on one photograph of the

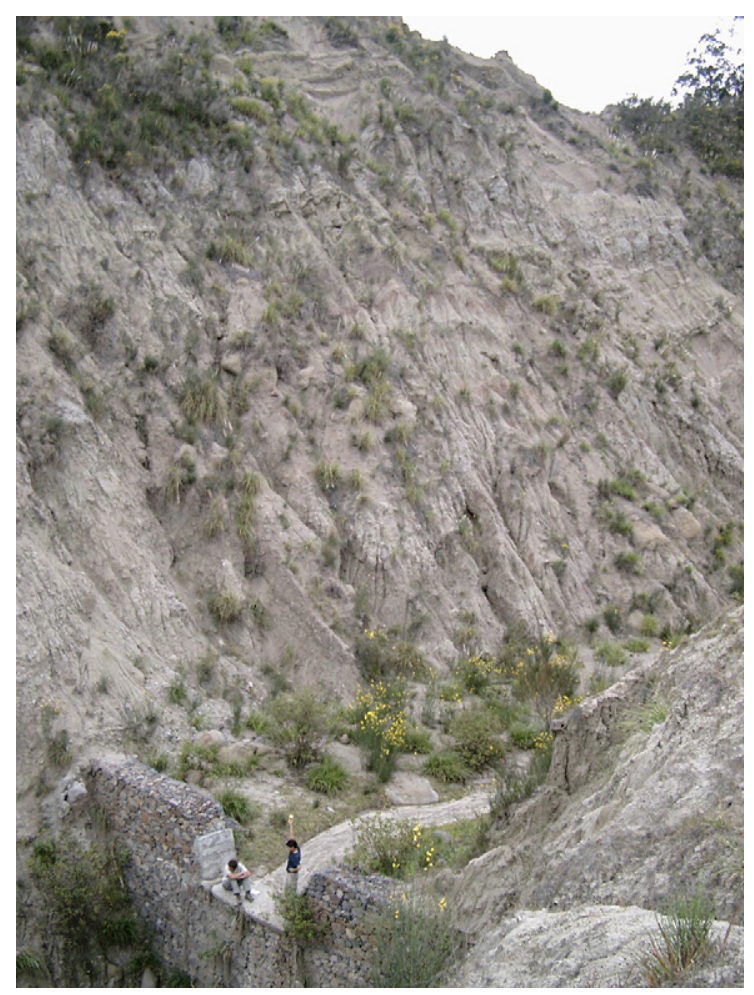

Fig. 2. Checkdams constructed in ephemeral stream channels to reduce the stream power (Caldera catchment). The mean annual sediment yield of this catchment of $1.48 \mathrm{~km}^{2}$ is the highest value that was measured in this region, and approximates $15,100 \mathrm{Mg} \mathrm{km}^{2}$ year $^{-1}$. 

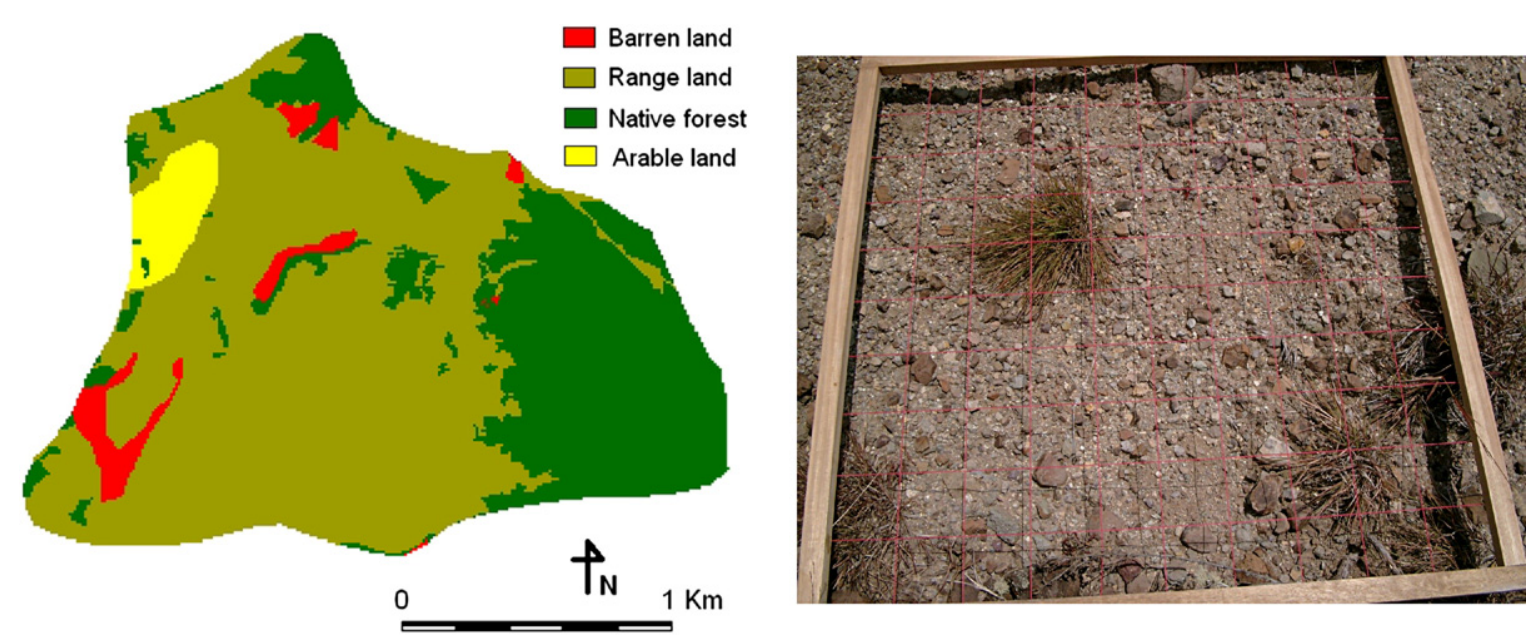

Fig. 3. The fractional vegetation cover was derived for each catchment by downscaling $1 / 10,000$ land cover with information from 1 by $1 \mathrm{~m}$ vegetation plots. The land cover maps were derived from aerial photographs of 1995 , which have an approximate scale of $1 / 35,000$, and were validated extensively in the field. The left picture shows an example of a land cover map from the Carmen1 catchment. Note that in this catchment, only four land cover classes exist. The picture on the right shows one of the 133 vegetation plots.

stereopair. By scanning and orthorectifying, the airphotos were digitized and corrected for distortion and relief displacement. The delineated land cover polygons were then digitized on-screen. For each of the seven land cover classes, 10 to 35 vegetation plots of 1 by $1 \mathrm{~m}$ were located on the reference land cover map. The surface vegetation cover was assessed visually from vertical photographs of the soil surface (Vandewalle, 2004; Herremans, 2005). All photographs were focused on a wooden frame with grid cells of 0.10 by $0.10 \mathrm{~m}$ (100 nodes) that was placed on the surface. The overall vegetation cover was then calculated as the percentage of nodes overlying vegetation fragments. Table 2 shows the vegetation characteristics of each land cover class. This information was combined with the land cover map to estimate the fractional vegetation cover for each catchment. The surface vegetation cover refers to the cover that is actually in contact with or very close to $(<0.10 \mathrm{~m})$ the soil surface and will therefore often be considerably lower than total vegetation cover.

\subsection{Analysis of the factors controlling sediment yield}

Univariate and multivariate statistical analyses were performed to analyze the dependency of the mean annual sediment yield on topography, soil types, lithology and vegetation cover. A data set was created, which contains for each catchment seven numerical (one dependent and six independent) variables (Table 1). First, univariate statistical techniques were used to explore the relation between the mean annual sediment yield (SSY) and each one of the catchment parameters. Spearman's Rank correlation analyses were performed on each pair of independent and dependent variables, and scatterplots were made to visualize the type and strength of the association. The magnitude of these coefficients is directly proportional to the sensitivity of the sediment yield to each one of the independent variables. Regression techniques were applied to explain the observed variability in SSY. As the distribution of the sediment yield data is skewed, the dependent variable was transformed by taking the natural logarithm of SSY data. The predictive efficiency of the regression model was evaluated based on the Root Mean Square Error (RMSE) and the Adjusted $R$-Square (Adj. $R$-Sq). Finally, the log-linear regression models

Table 2

Vegetation characteristics of each land cover class

\begin{tabular}{lll}
\hline & $\begin{array}{l}\text { Number of } \\
\text { vegetation plots }\end{array}$ & $\begin{array}{l}\text { Fractional vegetation cover }(C) \\
\text { (mean } \pm 1 \text { S.D.) }\end{array}$ \\
\hline Native forest & 7 & $0.99 \pm 0.03$ \\
Pine forest & 11 & $0.70 \pm 0.08$ \\
Eucalyptus forest & 16 & $0.67 \pm 0.13$ \\
Shrubland & 29 & $0.56 \pm 0.28$ \\
Arable land & 22 & $0.43 \pm 0.16$ \\
Rangeland & 11 & $1.00 \pm 0.01$ \\
Barren land & 37 & $0.08 \pm 0.08$
\end{tabular}

The fractional vegetation cover (mean \pm 1 S.D.) per land cover category was estimated from a large number of vertical pictures of 1 by $1 \mathrm{~m}$ vegetation plots. 


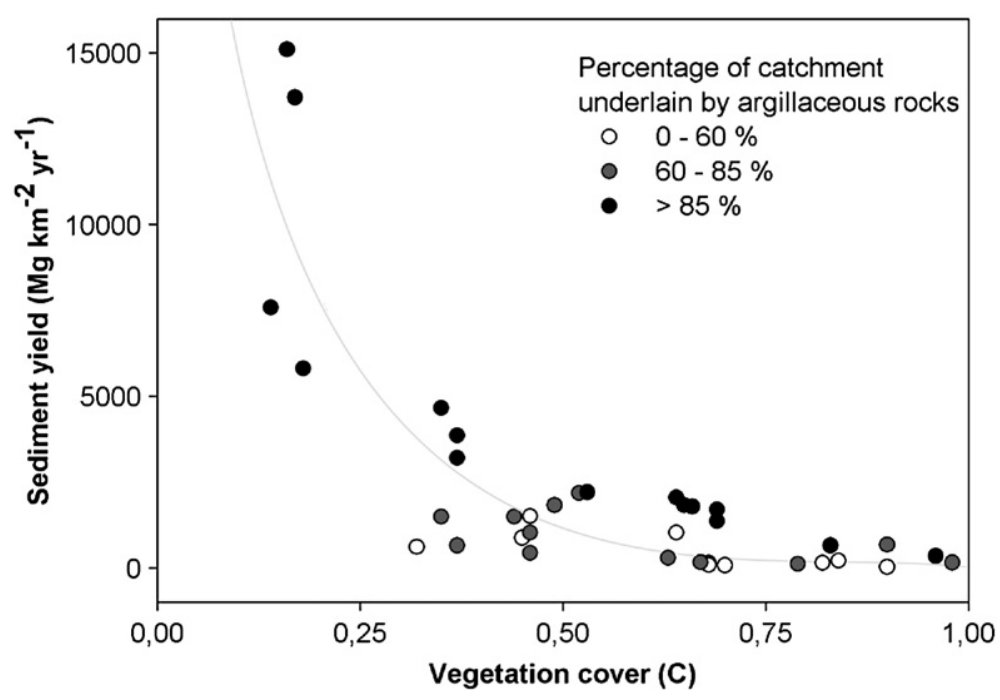

Fig. 4. Scatter plot of sediment yield $\left(\mathrm{Mg} \mathrm{km}^{2}\right.$ year $\left.^{-1}\right)$ versus vegetation cover $(C)$, with the percentage of the catchment underlain by argillaceous rocks as grouping variable. The solid grey line shows the negative exponential function between sediment yield and vegetation cover $\left(\mathrm{SSY}=20,500 e^{-4.91 C}\right)$ that best fits our observations.

were retransformed to the original units, and retransformation bias was corrected through the smearing estimator (Duan, 1983; Manning and Mullahy, 2001).

\section{Results and discussion}

A wide range in mean annual specific sediment yield (SSY, Mg km ${ }^{-2}$ year $^{-1}$ ) was observed for small catchments $\left(0.02-16.12 \mathrm{~km}^{2}\right)$ in the southern Ecuadorian Andes, with estimates ranging over three orders of magnitude (Table 1). The lowest observed sediment yield was $26 \mathrm{Mg} \mathrm{km}^{-2}$ year $^{-1}$ for a small forested catchment of $0.07 \mathrm{~km}^{2}$, and the highest observed sediment yield were 15,100 and $13,700 \mathrm{Mg} \mathrm{km}^{-2}$ year $^{-1}$ for highly degraded badland areas of 1.48 and $0.04 \mathrm{~km}^{2}$ respectively.

Analyses indicate that the specific sediment yield (SSY) is highly correlated with fractional vegetation cover $(C)$, and the percentage of the catchment underlain by argillaceous rocks $(L)$ (Fig. 4); on the

Table 3

Spearman's rank correlation coefficients between sediment yield and each one of the explanatory catchment variables

\begin{tabular}{llcr}
\hline & & $\begin{array}{c}\text { Correlation } \\
\text { coefficient }\end{array}$ & $p$-value \\
\hline Vegetation cover & $C$ & -0.71 & $<0.01$ \\
Fraction of argillaceous rocks & $L$ & 0.66 & $<0.01$ \\
Catchment area & $A$ & -0.54 & $<0.01$ \\
Fraction of highly erodible soils & SOIL & 0.28 & 0.09 \\
Mean slope & SL & 0.04 & 0.81 \\
Relief ratio & RR & 0.29 & 0.09 \\
\hline
\end{tabular}

other hand, it shows a weak, but significant correlation with catchment area $(A)$. Other catchment parameters such as slope gradient, relief ratio and soil type are not significantly linked to the sediment yield (Table 3). Sediment yield spans three orders of magnitude and shows a monotonous, but non-linear behaviour with vegetation cover, percentage of the catchment underlain by argillaceous rocks, and catchment area. Therefore, sediment yield was transformed by applying a natural logarithmic function on the SSY data.

Univariate regression analyses on the normalized data reveal that, of the variables listed in Table 3, vegetation cover exerts the strongest influence on sediment yield and has the highest predictive power $(R$-Square $=0.57)$ (Table 4). Vegetation cover protects the surface from raindrop impact, controls the surface infiltration rate, and reduces surface runoff, sediment detachment, and

Table 4

Table of the least-square parameter estimates of the multiple regression model for the prediction of sediment yield

\begin{tabular}{|c|c|c|c|c|c|}
\hline & & $\begin{array}{l}\text { Parameter } \\
\text { estimate }\end{array}$ & $\begin{array}{l}\mathrm{R} \\
\mathrm{RMSE}\end{array}$ & $\begin{array}{l}\text { Partial } \\
R \text {-Square }\end{array}$ & $\begin{array}{l}\text { Model } \\
R \text {-Square }\end{array}$ \\
\hline 1 Vegetation cover & $C$ & $-4.91 \pm 0.72$ & 0.19 & 0.57 & 0.57 \\
\hline $\begin{array}{l}2 \text { Fraction of } \\
\text { argillaceous rocks }\end{array}$ & $L$ & $2.73 \pm 0.41$ & 0.12 & 0.23 & 0.80 \\
\hline
\end{tabular}

Sediment yield data were transformed by applying a natural logarithmic function, and the model was selected stepwise. The uncertainty on the model fit is given by the Relative Root Mean Square Error (R RMSE), the partial and model $R$-Square. 
transport. In this study sediment yield decreases exponentially with an increasing vegetation cover, $C$. The following equation was obtained by fitting a negative exponential function to the data:

$\mathrm{SSY}=a e^{b C}$

where in our study area $a=20,500\left(\mathrm{Mg} \mathrm{km}^{-2}\right.$ year $\left.^{-1}\right)$ and $b=-4.91$ (dimensionless). At the catchment scale, almost $60 \%$ of the observed variance in sediment yield can be explained by the fractional vegetation cover in the catchment (Fig. 5).

This negative exponential relation between sediment yield and vegetation cover at the catchment scale is remarkably similar to empirical equations established for splash, rill and interrill erosion at the plot scale. A research review by Gyssels et al. (2005) on the impact of vegetation cover on erosion rates at experimental plots $\left(1-10^{3} \mathrm{~m}^{2}\right)$ showed that the decrease of relative water

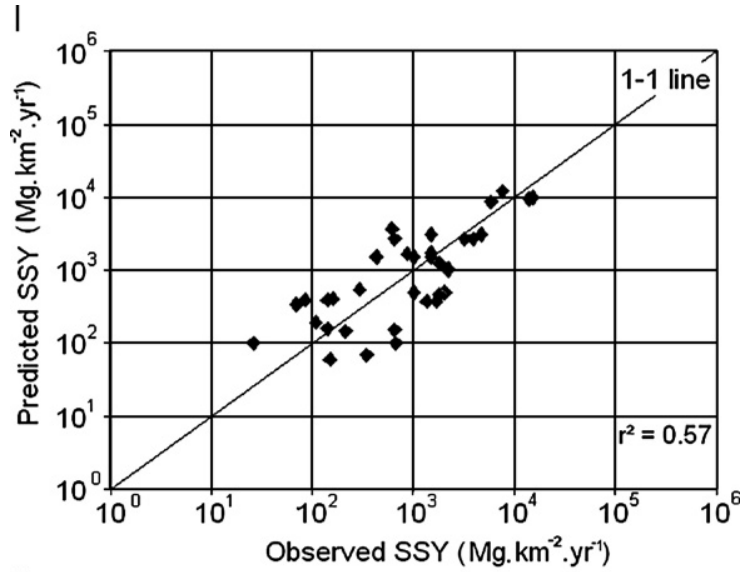

II

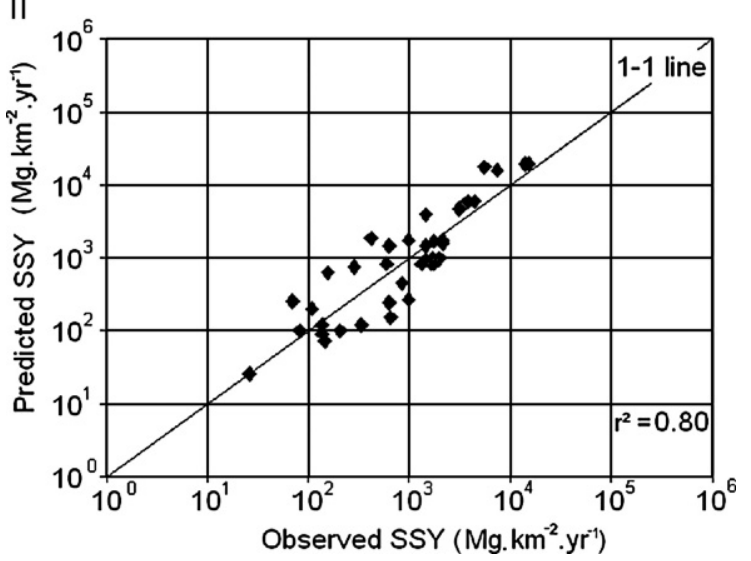

Fig. 5. Scatter plot of predicted versus observed sediment yield (SSY) for (I) regression model based on vegetation cover in close contact with the soil surface only, and (II) multiple regression model based on vegetation cover and lithology.

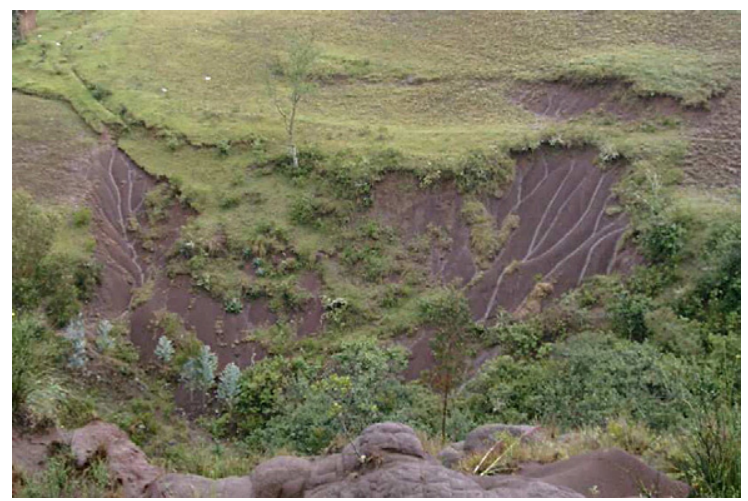

Fig. 6. Argillaceous rocks, highly susceptible to water erosion (Vegaspamba catchment).

erosion rates, $E$, with increasing vegetation cover is exponential according to the equation $E=e^{-b C}$, where $b$ is a constant indicating the effectiveness of the vegetation cover in reducing soil erosion rates. Our data indicate that the vegetation control on sediment yield is strong at the catchment scale $\left(10^{3}-10^{9} \mathrm{~m}^{2}\right)$, and similar to the one at the plot scale for splash ( $b$-value: $3.5 \pm 1.0$; Gyssels et al., 2005), interrill and rill erosion ( $b$-value: $4.8 \pm 2.0$; revised from Gyssels et al., 2005). Importantly, our data extend the negative exponential relationship between vegetation cover and sediment yield, which was derived for splash, interrill and rill erosion from numerous plot experiments worldwide, to the catchment scale. They show the general character of a first-order control of vegetation cover on erosion and sediment yield.

Notwithstanding a weak correlation between soil type and sediment yield (Correlation coefficient: 0.28, Table 3), the parent lithology significantly influences SSY (Correlation coefficient: 0.66, Table 3). This discrepancy can be explained by the development of similar soil types on distinct parent material. In this study, lithology $(L)$ explains an additional $23 \%$ of the total variance observed in sediment yield (Table 4). The presence of highly erodible argillaceous rocks, $L$, exponentially increases soil erosion risks. Particularly when the vegetation cover in the basin is degraded, surface material is easily detached by raindrop impact and entrained by surface runoff (Fig. 6).

A multiple regression model of sediment yield was built following the stepwise procedure, and using the logarithms of the observed sediment data. The resulting model was retransformed into the original units and retransformation bias was corrected according to Manning and Mullahy (2001). The model includes two independent variables: vegetation cover and 


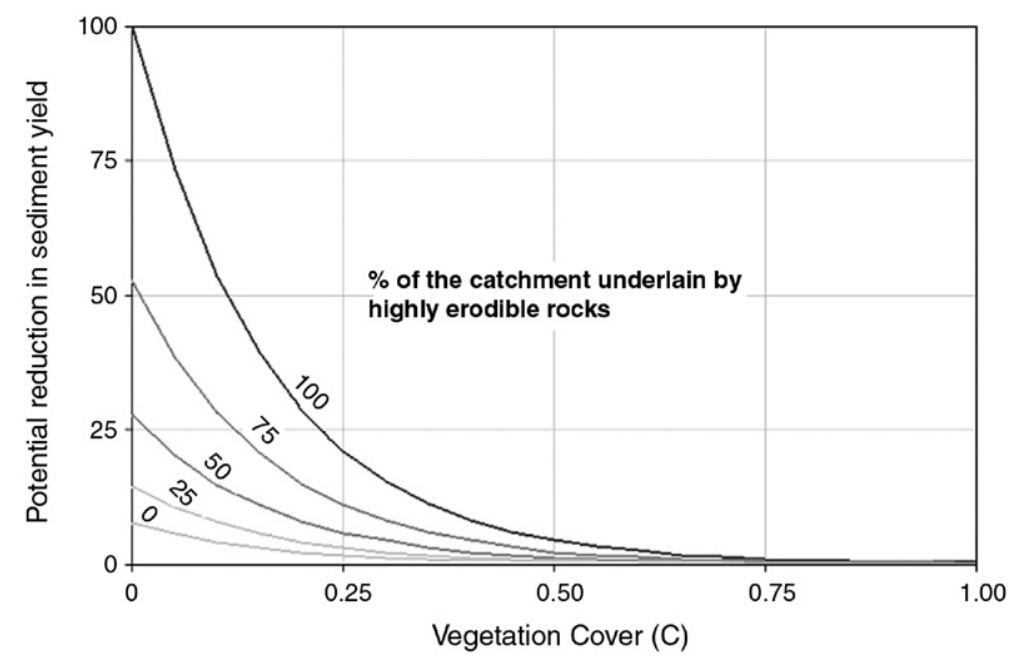

Fig. 7. Reduction in sediment yield with increasing vegetation cover, according to equation SSY $=a^{\prime} \times e^{c L+b C}$. All sediment yield data are shown as the percentage of the maximum sediment yield, i.e., relative to a catchment with bare soil underlain by argillaceous rocks.

lithology. The parameter estimates of the regression model, as well as the goodness of fit measures are given in Table 4. Sediment yield, SSY, increases exponentially with decreasing vegetation cover, $C$, and increasing presence of argillaceous rocks, $L$, according to the equation

$\mathrm{SSY}=a^{\prime} \times e^{c L+b C}$

where in this study area $a^{\prime}=2330\left(\mathrm{Mg} \mathrm{km}^{-2}\right.$ year $\left.^{-1}\right)$, $b=-4.91$ (dimensionless), and $c=2.73$ (dimensionless). This statistical model accounts for $80 \%$ of the total observed variance in sediment yield at the catchment scale, and all variables are statistically significant at $\alpha=0.01$ (Fig. 5). Vegetation cover exerts a first order control on sediment yield, and $57 \%$ of the observed variance in the logarithm of the sediment yield data can be explained only by differences in the fractional vegetation cover. An additional $23 \%$ of the total variance in the logarithm of the sediment yield data can be explained by variability in the underlying parent material.

Contrary to what was observed in previous studies (Desmet and Govers, 1995) and what is often considered to be a general tendency, catchment area (A) does not have a significant effect on sediment yield, once vegetation cover and lithology are accounted for. The main reason for the absence of an effect of $A$ on SSY is the topography of our study area. Slopes in the study area are very steep and are directly linked to the rivers. Thus, possibilities for sediment storage within the catchment are limited, so that sediment delivery does not decrease with catchment area. The specific topo- graphic characteristics also explain why average slope and/or relief ratio do not control sediment yield: indeed, slope gradients are relatively high in all studied catchments.

The empirical statistical model of sediment yield can be used to explore the effectiveness of soil erosion mitigation measures. In this case, the model predicts that revegetation of barren land has a strong potential for erosion mitigation, as an increase in vegetation cover by $25 \%$ on bare soil leads to a potential reduction in sediment yield by $80 \%$ (Fig. 7). This potential negative exponential decline of sediment yield with increasing vegetation cover is strongest in areas where argillaceous rocks are outcropping.

\section{Conclusions}

In this paper, the spatial variability in specific sediment yield (SSY) for 37 small mountainous catchments distributed throughout the southern Ecuadorian Andes was analyzed. Multivariate regression techniques were successfully applied to establish empirical functions, which describe the influence of catchment variables on sediment yield at the catchment scale. This study shows that sediment yield decreases exponentially with an increasing vegetation cover, and a decreasing percentage of the catchment underlain by argillaceous rocks.

Surface vegetation cover exerts a first order control on sediment yield at the catchment scale, as the fractional vegetation cover alone explains $57 \%$ of the observed variance in $\ln (\mathrm{SSY})$. The empirical function between vegetation cover and sediment yield, which was established 
here for 37 small mountain catchments, is similar to the equations established for splash, rill and interrill erosion at the plot scale. This affirms the general character of an exponential decrease of sediment yield with increasing vegetation cover at a wide range of spatial scales.

In addition to vegetation cover, the lithology of the area also influences the sediment yield of the catchment significantly. In this study, a strong contrast was found in the acceleration of erosion by vegetation removal between catchments underlain by meta-sediments, igneous and hard sedimentary rocks and by weak argillaceous rocks. The latter are more susceptible to detachment and entrainment of particles by rain and runoff when exposed at the surface.

This study on sediment yield in anthropogenically altered mountain basins shows that vegetation cover is the most effective catchment parameter in reducing anthropogenically increased sediment yield. Our data indicate that a small (10 to $25 \%$ ) increase in the contact vegetation cover can lead to a significant (60\%) decrease in sediment yield. This clearly points to the importance of vegetation cover close $(<0.1 \mathrm{~m})$ to the soil surface on erosion control, and highlights the large potential of revegetation programs for erosion mitigation.

\section{Acknowledgements}

Numerous individuals helped with the original field data collection on erosion rates and vegetation cover, including S. Herremans, E. Tacuri, A. Tiesters, and A. Vandewalle. This research was facilitated by a K.U. Leuven IRO Fellowship to A.M., and a Marie Curie EIF fellowship to V.V. We also thank the Flemish Interuniversity Council (VLIR-OI) for supporting the InterUniversity Project "Towards integrated catchment management in tropical mountain areas: the problem of sediment management, Paute River, Ecuador" between the University of Cuenca, Ecuador and the K. U.Leuven, Belgium.

\section{References}

Aristide, M., 2002. Stream bed stabilization using boulder check dams that mimic step-pool morphology features in Northern Italy. Geomorphology 45, 243-260.

Cerda, A., 1998. Relationships between climate and soil hydrological and erosional characteristics along climatic gradients in Mediterranean limestone areas. Geomorphology 25, 123-134.

Coltorti, M., Ollier, C.D., 2000. Geomorphic and tectonic evolution of the Ecuadorian Andes. Geomorphology 32, 1-19.

Commander, S., Peek, P., 1986. Oil export, agrarian change and the rural labor process: the Ecuadorian Sierra in the 1970s. World Development 14, 79-96.
Dadson, S.J., Hovius, N., Chen, H.G., Dade, W.B., Hsieh, M.L., Willett, S.D., Hu, J.C., Horng, M.J., Chen, M.C., Stark, C.P., Lague, D., Lin, J.C., 2003. Links between erosion, runoff variability and seismicity in the Taiwan orogen. Nature 426, 648-651.

Deckers, J.A., Nachtergaele, F.O., Spaargaren, O.C., 1998. World Reference Base for Soil Resources. Introduction. Acco, Belgium.

Dercon, G., Bossuyt, B., De Bièvre, B., Cisneros, F., Deckers, J., 1998. Zonificación Agroecológica del Austro Ecuatoriano. PromasUniversidad de Cuenca, Cuenca, Ecuador.

Dercon, G., Govers, G., Poesen, J., Rombaut, K., Vandenbroeck, E., Sanchez, H., Loaiza, G., Deckers, J., 2007. Animal-powered tillage erosion assessment in the Southern Andes region of Ecuador. Geomorphology 87, 4-15.

Desmet, P.J.J., Govers, G., 1995. GIS-based simulation of erosion and deposition patterns in an agricultural landscape: a comparison of model results with soil map information. Catena 25, 389-401.

de Vente, J., Poesen, J., 2005. Predicting soil erosion and sediment yield at the basin scale: scale issues and semi-quantitative models. Earth Science Reviews 71, 95-125.

de Vente, J., Poesen, J., Verstraeten, G., 2004. The application of semiquantitative methods and reservoir sedimentation rates for the prediction of basin sediment yield in Spain. Journal of Hydrology $305,63-86$

Dirección Nacional de Geología (DINAGE), 1974. Mapa geologico del Ecuador (1/100.000), hoja Girón, Gualaceo, Azogues, Cuenca. Ministerio de Recursos Naturales y Energéticos, Quito, Ecuador.

Duan, N., 1983. Smearing estimate: a nonparametric retransformation method. Journal of the American Statistical Association 78, 605-610.

Froehlich, W., Starkel, L., 1995. The response of slope and channel systems to various types of extreme rainfall: a comparison between temperate zone and humid tropics. Geomorphology 11, $337-345$.

Gyssels, G., Poesen, J., Bochet, E., Li, Y., 2005. Impact of plant roots on the resistance of soils to erosion by water: a review. Progress in Physical Geography 29, 189-217.

Herremans, S., 2005. Evaluation of infiltration characteristics of areas with different land cover using a portable rainfall simulator in the catchment of Jadan, Ecuador. Thesis, Faculty of Sciences, Katholieke Universiteit Leuven, Belgium.

Hess, C.G., 1990. "Moving up-moving down": agro-pastoral land-use patterns in the Ecuadorian paramos. Mountain Research and Development 10, 333-342.

Hewawasam, T., von Blanckenburg, F., Schaller, M., Kubik, P., 2003. Increase of human over natural erosion rates in tropical highlands constrained by cosmogenic nuclides. Geology 31, 597-600.

Instituto Ecuatoriano de Electrificación (INECEL), 1992. Mapas topográficos de las cuencas de los Ríos Burgay, Gualaceo and Jadán 1:10000. INECEL, Quito, Ecuador.

Litherland, M., Aspden, J.A., Jemielita, R.A., 1994. The metamorphic belts of Ecuador. Overseas Memoir, vol. 11. British Geological Survey, Keyworth, U.K.

Manning, W.G., Mullahy, J., 2001. Estimating log models: to transform or not to transform. Journal of Health Economics 20, 461-494.

Ministerio de Agricultura y Ganaderia (MAG) - Programa Nacional de Regionalizacion (PRONAREG), 1979. Soil map 1/50.000: Gualaceo, Cuenca, Azogues, Cañar, and Sigsig. MAG, Quito.

Montgomery, D.R., Buffington, J.M., 1997. Channel-reach morphology in mountain drainage basins. Geological Society of America Bulletin 109, 596-611. 
Palmieri, A., Shah, F., Dinar, A., 2001. Economics of reservoir sedimentation and sustainable management of dams. Journal of Environmental Management 61, 149-163.

Pimentel, D., Harvey, C., Resosudarmo, P., Sinclair, K., Kurz, D., McNair, M., Crist, S., Shpritz, L., Fitton, L., Saffouri, R., Blair, R., 1995. Environmental and economic costs of soil erosion and conservation benefits. Science 267, 1117-1123.

Programa para el Manejo de Agua y Suelo (PROMAS), 2001. Mapa de suelos del Austro Ecuatoriano. Universidad de Cuenca, Cuenca, Ecuador.

Snelder, D.J., Bryan, R.B., 1995. The use of rainfall simulation tests to assess the influence of vegetation density on soil loss on degraded rangelands in the Baringo District, Kenya. Catena 25, 105-116.

Strahler, A.N., 1964. Quantitative geomorphology of drainage basins and channel networks. In: Chow, V.T. (Ed.), Handbook of Applied Hydrology. McGraw-Hill, New York, pp. 439-476.

Thornes, J.B. (Ed.), 2001. Vegetation and Erosion. Processes and Environments. British Geomorphological Research Group Symposia Series. Wiley, Chichester.

Trimble, S.W., Crosson, P., 2000. Land use- US soil erosion ratesmyth and reality. Science 289, 248-250.

Vanacker, V., Govers, G., Barros, S., Poesen, J., Deckers, J., 2003a. The effect of short-term socio-economic and demographic changes on landuse dynamics and its corresponding geomorphic response with relation to water erosion in a tropical mountainous catchment, Ecuador. Landscape Ecology 18, 1-15.

Vanacker, V., Vanderschaeghe, M., Govers, G., Willems, E., Poesen, J., Deckers, J., De Biévre, B., 2003b. Linking hydrological, infinite slope stability and land use change models through GIS for assessing the impact of deforestation on landslide susceptibility in High Andean watersheds. Geomorphology 52, 299-315.

Vanacker, V., Molina, A., Govers, G., Poesen, J., De Bièvre, B., Deckers, J., 2007. Spatial variation of suspended sediment concentrations in a tropical Andean river system: the Paute River, southern Ecuador. Geomorphology 87, 53-67.

Vandewalle, A., 2004. Land use change in the Ecuadorian Andes: Burgay Catchment. M.Sc. Thesis, Faculty of Sciences, Katholieke Universiteit Leuven, Belgium.

Verstraeten, G., Poesen, J., 2002. Using sediment deposits in small ponds to quantify sediment yield from small catchments: possibilities and limitations. Earth Surface Processes and Landforms 27, 1425-1439.

Wunder, S., 1996. Deforestation and the uses of wood in the Ecuadorian Andes. Mountain Research and Development 16, $367-382$. 